\title{
Eurostudia
}

\section{Struggles for the Character of the Roman Catholic Church in Czechoslovakia, 1948-1989}

\section{Miroslav Tížik}

Volume 10, numéro 1, 2015

From Today's Observation Post: Collaboration and Resistance under Communism

Vues du poste d'observation du présent : collaboration et résistance sous le communisme

Kollaboration und Widerstand im Kommunismus - Betrachtungen aus heutiger Sicht

URI : https://id.erudit.org/iderudit/1033882ar

DOI : https://doi.org/10.7202/1033882ar

Aller au sommaire du numéro

Éditeur(s)

Le Centre canadien d'études allemandes et européennes

ISSN

1718-8946 (numérique)

Découvrir la revue

Citer cet article

Tížik, M. (2015). Struggles for the Character of the Roman Catholic Church in Czechoslovakia, 1948-1989. Eurostudia, 10(1), 51-73.

https://doi.org/10.7202/1033882ar
Résumé de l'article

After the Communist Party of Czechoslovakia came to power in 1948, power struggles followed between political parties and long-running internal struggles within the country's Roman Catholic Church over the church's character and organizational structure. These struggles related not only to purely theological issues, but also to the ideals of communism (and, later, socialism), the Communist Party and its program. The internal plurality within the church throughout the whole period of the people's democracy and state socialism in Czechoslovakia calls into question the dualistic image of struggles between the church and the Communist Party, and it complicates the image of the church as a victim of the Communist regime. In particular, the crucial periods from 1948 to 1952 and from 1968 to 1969 suggest that, throughout much of the communist period there persisted tensions between the higher and lower clergy and there were diverging views on how the church should function; these tensions took on a diversity of shapes and varied in intensity.
Tous droits réservés $@$ Le Centre canadien d'études allemandes et européennes, 2015
Ce document est protégé par la loi sur le droit d'auteur. L'utilisation des services d’Érudit (y compris la reproduction) est assujettie à sa politique d'utilisation que vous pouvez consulter en ligne.

https://apropos.erudit.org/fr/usagers/politique-dutilisation/ 


\author{
Miroslav Tížik \\ Institute for Sociology, Slovak Academy of Sciences
}

\begin{abstract}
:
After the Communist Party of Czechoslovakia came to power in 1948, power struggles followed between political parties and long-running internal struggles within the country's Roman Catholic Church over the church's character and organizational structure. These struggles related not only to purely theological issues, but also to the ideals of communism (and, later, socialism), the Communist Party and its program. The internal plurality within the church throughout the whole period of the people's democracy and state socialism in Czechoslovakia calls into question the dualistic image of struggles between the church and the Communist Party, and it complicates the image of the church as a victim of the Communist regime. In particular, the crucial periods from 1948 to 1952 and from 1968 to 1969 suggest that, throughout much of the communist period there persisted tensions between the higher and lower clergy and there were diverging views on how the church should function; these tensions took on a diversity of shapes and varied in intensity.
\end{abstract}

\title{
1 Introduction
}

One of the most common interpretations of Central and Eastern European history makes a sharp distinction between the periods before and after the Communist Party took power in a given country. Although these moments are not today considered to be revolutions (but more often are referred to as "putsches" or "coups d'état"), they are described as radical turning points in all spheres of a country's social, political, and economic life. According to such a view, the relation between the state and religion is considered to be an emblematic case of this kind of binary or dualistic transformation. ${ }^{1}$ In the case

\footnotetext{
${ }^{1}$ This approach to describing historical change is quite widespread in Central and Eastern European historiography and sociology. Many researchers do not analyze changes over the course of the regime's history but, rather, consider the entire period (from 1948 to 1989 in Czechoslovakia's case) as a single block of " 40 years of communism," which followed a radical turning point (Kvasničková 2005; Čikeš 2010; Václavík 2010). This approach has, however, been the target of methodological criticism (see, for example, Pullman 2011).
} 
of Czechoslovakia, most historians identify the turning point as the "Victorious February 1948" (a.k.a. "the 1948 Czechoslovak coup d'état"), when the Communist Party seized political power in the country. This change of regime involved several levels of conflict in Czechoslovak society:

1. Struggles over power among political parties;

2. Struggles over the character of the state, including tension surrounding the principles of equality versus hierarchy, tension between the "bourgeoisie" (as some historians call the type of democracy Czechoslovakia had during the 1918-1938 and 1945-1948 periods) and the notion of a people's democracy, and tension over the symbolic adhesion to the West versus the East (as part of the Cold War);

3. Long-term internal struggles within the Catholic Church over the character of the church and the way it should be organized.

In reflecting on the character of churches and religious life, dualistic approaches in historiography stress the state's role as an oppressor of religion and as an instrument of the Communist Party in its fight against the church and religion (Balík and Hanuš 2013). Such interpretations accept at face value the self-descriptions of the churches, priests, and believers as victims of the Communist regime. A little more than half a century after the political turning point that brought the Communist Party to power, history-in the dominant interpretation of this period in Central and Eastern Europe-has become more of a political instrument than a tool of scientific analysis. ${ }^{2}$ This focus on the change of political regimes draws attention away from shifts and transformations that took place in various actors involved in these changes.

As the Communist party in Czechoslovakia took power at the end of February 1948, struggles ensued not only among political parties vying for power, but also within the Roman Catholic Church (the largest church in Czechoslovakia) over its character and organizational structure. These internal struggles concerned not only purely theological issues, but also the ideals of communism-or, later, socialism-as well as the Communist Party and its program. By studying the relationship between religion and the state and the role of religion during the period of the people's democracy and state

\footnotetext{
${ }^{2}$ James Krapfl (2014) stresses the role of the interpretation of history as a part of a mythology legitimizing or delegitimizing a system.
} 
socialism, ${ }^{3}$ we can demonstrate not only the changing nature of the regime during the 40 years of its existence, but also the changing relationship between religious bodies and the ideology and institutions of the regime.

The time spanning between 1948-1989 can be divided into six periods according to the type of relationships between the state and the Catholic Church; in each period, this relationship was deeply connected with internal struggles over the church's character, which intensified and, in some cases, led to schisms within the church. The changing position of the church in public and political life, together with the changing international situation, influenced opportunities available to movements inside the church as they sought to establish themselves as the church's main source of legitimacy and ideals. Balík and Hanuš (2013) note the existence of three Catholic Churches in Czechoslovakia between 1948 and 1989: a) the official church, which supported the regime, b) the unofficial church, and c) the church in exile. They understand the official church as a collaborator with the regime and the unofficial and exiled churches as resisting and united by opposition to the Communist Party in the power as their common enemy. ${ }^{4}$

Just as the relations between the state and the Catholic Church, represented by the Holy See and the bishops in Czechoslovakia and its own legislative framework, took on various forms at different times, so too did the divisions within the church. In order to achieve an understanding of these changes, it is necessary to move beyond a dualistic approach to explaining the relations between church and state. Even after the Communist Party had taken power, some Catholics took advantage of the opportunity to be active in political life and to be a part of the political elites at all levels of national policy. At the same time, as a result of a process of schismogenesis, that is, as a gradual creation of division between the state and the churches, took place within the churches themselves as state control was established over churches. One group of priests and church members (the so-called "progressive priests

\footnotetext{
${ }^{3}$ In this text I do not employ the term "communism" to describe the period between 1948 and 1989. I refer rather to two constitutional periods of Czechoslovakia: first as a "people's democracy" (19481960) and, later, as a "socialist republic" (1960-1989). There exist also other stages in the regime (such as the federalization of the state in 1968), but they are not important in the context of this study. I consider "state socialism" to be a generally more adequate term than "communism."

${ }^{4}$ As a part of this integrated protesting church, they also identify a so-called the secret church, in which they distinguish at least three subgroups.
} 
and laity"5) supported the policy of the people's democracy, while another group took a neutral position or set up parallel, or secret, structures and, in some cases and periods, ceased all public activity.

In this article I present the struggles over the character of the Catholic Church in three steps. First, I describe the historical and political context of the beginning of Communist Party rule. I then distinguish six periods in the development of church-state relations. In order to illustrate the dynamics of the changing character of the regime, I turn to the individual profile of one important actor these changes and introduce the story of Josef Plojhar, a Catholic priest, as an archetype of a Catholic actively participating in the public sphere from the end of World War II until the late period of the state socialist regime.

\section{The Context of Establishment of the People's Democracy}

In order to better understand the changes that took place during the first period of the new so-called people's democracy, it is important to note several particularities in the Czechoslovak case, but also a number of similarities between it and other European countries (including those of Western Europe). Beginning in 1948, the dispositions of various actors in the fields of politics and religion were influenced by a number of key factors, including broad historical and civilizational changes, the international political situation, national politics, the legitimacy of power, and the specific religious landscape of Czechoslovakia.

\subsection{Historical Factors Relating to Changes in the Religious Field in Czechoslovakia}

Three important circumstances shaped changes in the religious landscape:

a) The legacy of the anti-Catholic or anti-clerical movement from the period of the first Czechoslovak Republic (1918-1938): this movement had called for a state independent from the influence of churches, national politics independent from the Vatican, a secular educational system, and cadastral reform (the acquisition of church property, which had begun but was not completed). This anti-Catholic legacy was also related to an official policy

\footnotetext{
${ }^{5}$ The terms "progressive" and "patriotic" were applied to those priests and lay church members who, from the end of the 1940s until the 1960s, supported the policy of the people's democracy and established connections with leftist movements and political parties. Later, after the establishment of the official "peace movement," these priests were also referred to as "peace priests." These terms can therefore be employed as synonyms.
} 
of dissociating from German principles in culture and history, as advocated by the Saints Cyril and Methodius Movement, which emphasized the Slavic character of religion and somehow contributed to the nationalization of Christianity in Czechoslovakia. ${ }^{6}$

b) Post-war conditions: the Catholic Church had collaborated with fascist and totalitarian regimes in the wartime Slovak State (1939-1945); at the same time, there was a strong antifascist movement within the churches (including Catholics and Orthodox Christians in the Czech Lands as well as Greek-Catholics, Lutherans, and some Catholic priests in Slovakia); church property measuring over 50 hectares and the property of collaborators was nationalized in 1945; there was increased public, intellectual, and political trust in the Soviet Union as a symbol of liberty, which was given credit for liberating the country.

c) Theological modernist movements within Christianity in general and within the Catholic Church specifically: the Movement for Christian Communism (and the journal Slovak Christian Socialist [Slovenský krestanský socialista]), active already during the first Czechoslovak Republic; a movement for liturgical reform in the church (such as the use of national languages, the ordination of women, the abolition of celibacy, changes in the liturgy and greater independence from the Vatican); the Saints Cyril and Methodius Movement emphasizing national and general Slavic principles; attempts to create a national church (which achieved only partial success with the creation of the Czechoslovak Church in the Czech lands); the ecumenical movement.

\subsection{General Civilizational and Cultural Changes after WWII}

After WWII, throughout Europe an increasing secularization and state neutrality toward religion occurred also due to the wartime experience with clerical-fascist regimes. The strong influence of communism was also being fashionable with some segments of the population. The building of welfare states began and the increasing influence of the ideals of progress and scientific thinking as alternatives to religion started to be significant features of the spirit of the time.

\footnotetext{
${ }^{6}$ In a book only marginally devoted to case of Czechoslovakia, Gilles Kepel (1991) has been one of the surprisingly few authors to stress the continuity of the politics of the Communist Party with the policies of the first Czechoslovak Republic. In spite of their detailed description of the history of the relationship between the state and the Catholic Church in Czechoslovakia after WWII, Balík and Hanuš (2013) do not mention continuity with the first Czechoslovak Republic. Instead, they stress the similarities of communist religious policies with the policies of the Enlightenment-era monarchs Maria Theresa (1717-1780) and Joseph II (1741-1790).
} 


\subsection{International Political Situation}

With the beginning of the Cold War and Czechoslovakia's position as a country in the sphere of Soviet influence, the country chose not to sign on to the Marshall Plan (the European Recovery Program) but preferred the reconstruction help of the Soviet Union. At the same time, the Catholic Church, as the largest church in the country, was still under the direct influence of the Vatican's anti-communist foreign policy.

\subsection{National Political Conflicts}

The power struggle started between a unified Communist Party in all of Czechoslovakia and a divided opposition in two separate parts of the state, represented especially by the Czechoslovak People's Party in the Czech lands and the Democratic Party in Slovakia. Political opposition was limited by a system of a "National Front" of legal political parties, ${ }^{7}$ in which the Communist Party occupied the dominant position. The clergy was divided into two main political camps according to its political preferences-the higher clergy, which supported non-Communist parties, and the lower clergy, which in large part supported the Communists. Bishops prohibited priests from joining political parties without their permission; only priests in higher positions in the Czechoslovak People's Party were granted such a permission—e.g., Ján Šrámek and František Hála (Balík and Hanuš 2013: 128).

\subsection{The Confessional Structure of Czechoslovakia}

The religious composition of the Czechoslovakia was pluralist with one dominant supranational Catholic Church, which-like the Communist Partyhad institutional structures in both parts of Czechoslovakia (in the Czech lands involving $76 \%$ of the population and $76 \%$ of the population in Slovakia). The smaller churches had the following composition: the Czechoslovak Hussite Church (Czech lands-10.6\%, Slovakia less than 0.5\%), the Czech Evangelical Church of the Brethren (Czech lands 2.7\%, Slovakia less than $0.5 \%$ ), Greek Catholics (Czech lands less than 0.5\%, Slovakia 4.5\%), the Evangelical (Lutheran) Church (Czech lands less than 0.5\%, Slovakia 12\%), the

\footnotetext{
7 The National Front was a coalition of parties that formed the re-established Czechoslovak government between 1945 and 1948. During the period of state socialism (1948-1989), it was controlled by the largest political party, the Communist Party of Czechoslovakia.
} 
Reformed (Calvinist) Church (Czech lands less than 0.5\%, Slovakia 3.2\%), and the Orthodox Church (Czech lands less than $0.5 \%$, Slovakia about $1 \%$ ). ${ }^{8}$

\subsection{The Legitimacy of the New Power of the Communist Party}

Since the end of WWII, the dominant Communist Party had used the mass media and mobilized its membership infrastructure for large public campaigns-for example, against war and for peace. During the free elections of 1946, the Communist Party won a plurality of votes in Czechoslovakia as a whole, thanks in large part to massive support in the Czech lands (where it won $43 \%$ of the vote; in Moravia, the Eastern part of the Bohemia, it won 34\%, and in Slovakia 30\%). Only in Slovakia did it come in the second place, after the Democratic Party, which won $62 \%$.

All these circumstances created a specific constellation of a "socially constituted system of dispositions," as Pierre Bourdieu (1990: 55) called them, of various individual and collective actors. The case study of the Catholic priest Josef Plojhar presented in the last part of this article will show that, even after the Communist Party had taken the power, some Catholics took advantage of the opportunity to be active in political life and to be a part of the political elites.

\section{The State-Church Conflict as a Case of Schismogenesis}

A detailed reconstruction of the processes of establishing the Communist Party rule in Czechoslovakia reveals two parallel tendencies: a gradually intensifying conflict between the state and the churches (especially the Catholic Church), as well as a kind of schism within the Catholic Church itself. The concept of schismogenesis, as coined by Gregory Bateson (1972), can be used as an analytic tool for understanding this process of progressive differentiation between social groups or individuals. ${ }^{9}$ In analyzing the ongoing conflicts, one can identify several stages in the relationship between church

\footnotetext{
${ }^{8}$ These data on religious composition of Czechoslovakia are from the 1950 census, two years after the Communist Party took power.

${ }^{9}$ According to Bateson, schismogenesis as a creation of division, exists, for example, if two groups exhibit symmetrical behavior patterns towards each other that are different from the patterns they exhibit within their respective groups. They can set up a so-called "vicious circle" relation. Bateson describes two basic types of schismogenesis. One type is symmetrical: the behaviors of each party involved elicit similar or symmetrical behaviors in the other party or parties. The other type is complementary: the interaction between two groups of people is such that behavior $X$ from one side elicits behavior $Y$ from the other side. The differing behaviors complement one another, as exemplified in the dominant-submissive behaviors of class struggle. Furthermore, opposed behaviors may exacerbate one another, leading to a severe rift and possibly outright conflict.
} 
and state, not only at the outset of the state socialist regime, but also during the 40 years of its existence in Czechoslovakia. The state-church relationship that developed can in part be traced back to factors within the Catholic Church. The developing state-church relationship also had consequences on the character of the church, as it led to a series of parallel schisms.

These two conflicts, between church and state and within the church itself, are interconnected, and rooted in the broader post-war political conflicts. Until the Communist Party seized power in Czechoslovakia in the period from 1945 to 1948, Catholics were primarily members or supporters of three political parties: the Communist Party (in the Czech lands and Slovakia, supported largely by the lower clergy and laity of working-class background), the People's Party (in the Czech lands, supported largely by the higher clergy, farmers, and businesspeople), and the Democratic Party (in Slovakia, supported, like the Czech People's Party, largely by the higher clergy, farmers and businesspeople).

During the governmental crisis of February 1948, when the Communist Party took power, political conflict was widespread. An important change took place in the positions of various actors. The institutional transformation gave power and confidence to Communists and their supporters. As a consequence the People's Party and the Democratic Party, along with their supporters, took on the role of opposition. Opportunities for greater influence then opened within the sphere of churches and religion in general for clergy connected with the Communists who could also see their influence increased at the expense of the higher clergy. At the end of 1940s the church was described as divided into three groups according to its constituents' attitudes toward the new regime (Balík and Hanuš 2013: 22): 1. radically opposed, 2. conciliatory, and 3. capitulary-collaborationist (the latter category mostly composed of the so-called patriotic priests).

At the outset, the new regime did not position itself against religion or against the activity of priests in public life. The Communist Party expressed, on the contrary, interest in working together with churches, especially the Catholic Church. The struggle against the church and religion in general was initiated later, especially after 1951 (Kmet' 2000) and 1953 (Mišovič 2001; Pešek and Barnovský 1997). 
Already in its first months, the new regime worked quite intensely with members and some structures of the Catholic Church:

a) So-called "Action Fives" (Akčné pätky), five-person committees established by national committees (that is, local governing councils) in the villages and towns around the country to promote institutional, administrative, and political change. "Action Fives" were created with the participation of priests.

b) The new government and its coalition, the National Front, issued a declaration in favor of cooperating with the churches and with "progressive" people and groups (including churches); it also called on churches and other interested actors to participate in the structures of the National Front.

c) On 14 June 1948, in the Catholic cathedral in Prague, Te Deum was performed by the church welcoming "the first working-class president" of Czechoslovakia, Klement Gottwald. The bells of all the churches around the country were rung to celebrate the new head of state.

d) The 1948 constitution of the new "people democracy" recognized its Christian roots in progressive and antibourgeois movements (including Eastern Christianity and the Hussite rebellion) and in struggles against German oppression; it guaranteed religious freedom, equality among religions, and the freedom to confess no religion. Some churches-most notably the Orthodox Church-participated in drafting the constitution.

e) The Communist-led government issued a ritual greeting on the anniversary of funerals of church representatives.

This was only the beginning of the process of transformation undergone by the political regime and of the relations between religion and the state.

\section{Various Forms and Periods of Schismogenesis at the Time of State Socialism}

The year 1948 can be seen as the beginning of multiple forms of schismogenesis in Czechoslovakia. The main features of two basic types of schisomgenesis can be found throughout the whole period of the state socialism from 1949 to 1989. One type of schismogenesis is symmetrical, and it means a competitive relationship; another type is complementary, and it 
means the creation of a relationship of dominance and submission between two groups of people.

Beginning in 1948, one can distinguish six periods in the development of religious groups in Czechoslovakia:

1. A symmetrical schismogenesis between the state and churches and a form of schism within churches themselves (1948-1949)

2. A complementary schismogenesis (1949-1952)

3. The stabilization of Communist Party dominance (1953-1962)

4. The weakening of the asymmetrical relations between Communists and Catholics (1963-1967)

5. A second schismogenesis inside the Catholic Church (1968)

6. The stabilization of the privileged position of the Communist Party and increased conservatism within the Catholic Church (1969-1989)

\subsection{A Symmetrical Schismogenesis between the State and Churches and a Form of} Schism within Churches Themselves (1948-1949)

During this period of schisomogenesis (see tables 1 and 2 in the annex), the Communist Party did not actively fight against religion or priests in general, although it engaged in an intense effort to eliminate the power and public influence of the Catholic Church. During this period the Communist Party welcomed priests among its members encouraged them to be politically active. One civil servant responsible for the state's church agenda considered it a success that two priests in one particular district became members of the Communist Party in 1949, and that one of them became president of the local self-governing "national committee" (Stehlík 2008: 54).

\subsection{A Complementary Schismogenesis (1949-1952)}

As a result of the first schismogenesis, state control was established over churches, and a schism took place within the churches themselves (see table 3). One group of priests and church members ("progressive" priests and laity) supported the policies of the people's democracy while another created parallel, or secret, structures and in some cases ceased public activities. The first group was integrated into the officially recognized Peace Movement of 
Catholic Priests, the movement of supporters of people's democracy. In the early 1950s, nearly half of all 3,000 priests in Czechoslovakia were more or less active in this movement (Balík and Hanuš 2013: 127). The conflict between the state and the Vatican was institutionalized: the highest clergy, loyal to the Vatican, was isolated from the active life of the churches, and a new official church hierarchy was formed. The basis of a system of church regulations was now established, that persisted with only small modifications until the end of 1989.

\subsection{The Stabilization of the Dominant Position of the Communist Party over Churches in Czechoslovakia (1953-1962)}

During the period of the establishment of the new regime in Czechoslovakia, the dominant Communist Party of Czechoslovakia did not consider it a contradiction for its members to profess Christian faith. In 1953, however, after its position of power was stabilized, it initiated a public campaign calling on people to abandon the churches and later prohibited party members from occupying some posts in public administration and education, if they were openly religious.

Although some priests were still subject to political trials, amnesty was granted to political prisoners, including some priests, in three waves: in 1960, 1962, and 1965. Similarly, new church structures became as stable as state institutions. Darina Bancíková, a Lutheran priest and political prisoner in the 1960s, described how the state was present in all the state-recognized churches: "The New Church management has the confidence of state institutions. If we criticize our management, if we oppose their policies, then at the same time we criticize the state and are against the state" (Bancíková, undated: 13).

\subsection{The Weakening of the Asymmetrical Relations between Communists and Catholics (1963-1967)}

In spite of the interconnection between church management and the state institutions that controlled them, the international situation, coupled with profound changes within the Catholic Church, affected the position of the church in Czechoslovak society and called into question the legitimacy of its ideological program. 
The Second Vatican Council changed official church policies in several ways, thus meeting some of the demands of progressive movements that were expressed in the first half of the $20^{\text {th }}$ century. The change in attitudes toward communist countries was called the new Ostpolitik of Vatican. The Holy See accepted the communist regimes as "stabilized and enduring" (Balík and Hanuš 2013: 41). Some of the Council's policies influenced the church's relationship to the Czechoslovak state: a) the Church weakened its official anti-Communist stance; b) it approved performing the liturgy in vernacular languages; c) it emphasized the central role of the Bible; d) it called for increased equality among the clergy and increased involvement of the laity in the church life; e) it abandoned the idea that states should rule according to the principles of the church. In addition, ecumenical initiatives started to be an important part of the church program.

As the Council was reaching its end in 1965, the Vatican nominated as Prague administrator František Tomášek, a bishop consecrated clandestinely, a prisoner but also an ex-member-for a short period of time in 1948-of the committee of "Progressive priests." This can be seen as a notable shift in power inside official Catholicism in Czechoslovakia.

While the Vatican met a large number of the demands of the modernist theological movements (including the movement of progressive priests in Czechoslovakia), it weakened the reform spirit and potential of Czechoslovakia's new official clergy, which was compromised by its collaboration with the power structures of the Communist Party. After the Council, the progressives lost their power inside the Catholic Church; and, at the same time, the state lost its ability to hold up the Catholic Church as an enemy as it had done before the Council.

\subsection{A Second Process of Schismogenesis inside the Catholic Church (1968)}

The Prague Spring, the movement for reforming socialism in accordance with the ideals of "socialism with a human face," began in January 1968 after the Communist Party presidency went to the reformist Alexander Dubček. The Prague Spring also marked the formal end of "New Catholicism," or "Catholic Communism" in Czechoslovakia. On 21 March, the official Peace Movement of Catholic Priests, the movement for equality among priests and for the promotion of socialism in Christianity, collapsed, as its members considered reforming their structures in accordance with the Prague spring ethos. 
In place of the Peace Movement, which had voluntarily eliminated itself (mostly at the initiative of its Czech members), a new theological movement, called the Work of Council Renewal (WCR) was created. From the beginning it was under the leadership of secret bishop František Tomášek, a victim of the Communist regime who was tolerated by the regime at that time. In spite of this movement's reformist spirit, it was organized according to conservative hierarchical principles, including support for a hierarchical structure headed by bishops. However, it involved stronger participation of the laity in church life. The WCR called for a new dialogue with the Vatican. It was also influenced by a spirit of vengeance-some groups of lay members, sometimes supported by priests in exile or secret priests-became violent and aggressive toward priests connected with the regime and with the Communist Party. Some priests and members of the higher clergy resigned or died after facing public verbal attacks or pressure from the new movement. The WCR movement was stopped in its effort for legalization and official recognition by the state soon after the invasion of the armies of the Warsaw Pact on 21 August 1968, after which date the state refused to recognize this organization as a legal entity.

\subsection{The Stabilization of the Privileged Position of the Communist Party and Increased \\ Conservatism within the Catholic Church (1969-1989)}

Although the Communist Party lost much legitimacy after the replacement of Alexander Dubček by Gustáv Husák as the leader of the party in 1969, it stabilized its power in the country. The party also resumed its policies toward religion and churches from before the Prague Spring of 1968. The Central Committee of the Communist Party stressed in May 1970 the necessity of intensifying the ideological struggle, with a special focus on intellectuals and youth. Although a latent conflict between the state and churches was still present, a high level of religiosity among citizens-including Communist Party members-was tolerated (Kmet' 2014: 176). After the collapse of the "Peace movement" and the end of the WCR, a new peace movement of priests-Pacem in Terris-was established in 1971 under the control of the Communist Party; it existed until the end of 1989. This new organization repeated as its credo an older statement that socialism represented the practical realization of Jesus Christ's ideals (Kmet' 2014: 174). The first half of the 1970s was, according to Balík and Hanuš (2013), a period characterized by the triumph of the state over the church. It was also a period of powerlessness 
for the Vatican in its attempts to exert control over some secret bishops whose activities it was not always able to prohibit.

Within the Catholic Church, a schism emerged as a new underground church was created, mostly in the Slovak part of republic. The underground church was formed primarily by laity and clergy who were persecuted by the regime. Some of the underground church members had established parallel structures already in the 1950s, and they continued supporting a conservative theology, the hierarchical structure of the church (with a greater participation of laypeople) and a close connection with the Vatican and Catholic groups in exile. Another part of the underground church was a continuation of the WCR from 1968. A conservative program and a strict refusal of collaboration with ex-members of the Communist Party of the underground church led some of the groups to reject the dissident program Charter $77 .{ }^{10}$ Archbishop František Tomášek also refused to support this document, as it was not in accord with the church program. Only some groups of the underground church in the Czech lands supported the Charter 77, which called also for the application of the principles of religious freedom.

Although the dominance of the state over the church continued until the end of 1989, the situation inside of the church was changed in the second half of the 1970s. Karol Wojtyła's election as Pope John Paul II in 1978 brought renewed support for conservative theology and for opposition to Communism and "progressive movements" in the Catholic Church in Czechoslovakia. Conflict inside the Catholic Church was renewed by the Pope's decision to unrecognize the official structures of the church in Czechoslovakia that were integrated into Pacem in Terris. After thirty years of struggle between the Communist Party in Czechoslovakia and the Catholic Church, this represented the Vatican's first success (in the sense of real discreditation of a movement collaborating with Communists in the eyes of believers and younger priests). Interest in religious life rose among the population, and the activities of believers increased, in both the underground and the official churches. From the mid 1980s onward Catholics enjoyed a series of successes-a mass of believers participated in the pilgrimage to Velehrad, a public petition for religious freedom was signed, and the separation of church and state was

\footnotetext{
${ }^{10}$ This document was initiated not only by anti-Communists but also by ex-Communists, mostly reform-oriented Communists from 1968 who were expelled from the Party in 1969-1970.
} 
demanded at a public "candle demonstration" protest in the church in Bratislava in 1988.

The 1988-1989 period can be seen as the end of official church structures and as the recognition of the conservative underground church as a paradigm of the church and as an important anti-Communist actor. Reformist and progressive theology was, as a consequence, delegitimized. As a parallel process, the basis of the reception of the Second Vatican Council in Czechoslovakia was weakened.

What were the basic changes during forty years of state socialism in the life of religions and churches in Czechoslovakia? According to results from the 1950 census, the majority of the population declared some religious affiliation (99\% in Slovakia and 94\% in the Czech lands), and a small decline in the number of people without religious affiliation was noticed in comparison with the 1930 census. In both parts of the country, more than three quarters of the population declared itself Catholic $(76 \%)$. This means also that most members of the Communist Party were still members of some religious groups, mostly Catholics (Tížik 2011). The first period of the new regime involved a series of struggles for the soul and loyalty of the people, for the future of Czechoslovak society as whole and the relationship between the church and the state, in which the state sought to reach some kind of agreement on collaboration with churches (Kmet' 2000). At the beginning of the regime, many priests were included in the creation of its new political structures; they were, for example, active in processes such as the collectivization of agricultural production. Although the state-and the Communist Party-progressively came to occupy a dominant position and established a strong asymmetrical control over religious life, it was not able eliminate religious groups' influence in society and to completely control the Catholic Church.

Inside the Catholic Church, after the first divisions between pro-Vatican and progressive movements, later developments in national and international policies weakened the influence and legitimacy of the liberal groups connected with the Communist Party. After the Second Vatican Council, which met most of the demands of the "New Catholicism" in Czechoslovakia, this movement lost momentum. The principle of equality among the priests was slowly replaced by a new, more hierarchical program of integrating the laypeople under the leading role of bishops and higher clergy. This model also became 
an ideological source for the transformation of the church after the end of state socialism, providing a source of legitimacy for the new regime. The power change within the Catholic Church in Czechoslovakia after 1989 has also changed the interpretation its role in the period of state socialism and has led to a dualistic model of history, which portrays the church as a victim of an oppressive system. This view became the dominant pattern for historical interpretation.

\section{Writing Another History of the Church}

From the fall of state socialism on, researchers embarked on writing a new, non-Marxist and non-communist history. In the study of role of religion in the second half of $20^{\text {th }}$ century, churches started to be described as victims of the communist regime and as symbols of resistance against undemocratic regimes. In this process, the priests' roles and their support for the people's democracy and for the Communist Party was not investigated in details. In the concluding part of this article, my goal is to try to escape such a dualistic approach to the interpretation of history and to show the ambivalent role played by churches in the creation of various features of the state socialism in Czechoslovakia in presenting one case, that of priest Josef Plojhar (1902-1981).

It is difficult to reconstruct from a value-neutral point a portrait of Plojhar. He is mentioned in historical literature quite often, but mostly in brief comments and only for his activity as a politician and representative of Catholic associations. Often he is labeled, without further explanation, as a "fifth column," an "exponent of regime," an "exponent or collaborator of the totalitarian system," a "priest-collaborator" (Pešek and Barnovský 1997; Pešek and Barnovský 1999; Balík, and Hanuš, 2013). His portrait can only be rendered by drawing on notes or fragments about his activity and political engagement texts. ${ }^{11}$

Josef Plojhar was born in České Budějovice in a Czech-German family under the Austro-Hungarian Empire. After the creation of Czechoslovakia, he studied to become priest. During his secondary education at a German

\footnotetext{
${ }^{11}$ For example, Balík and Hanuš give us a small personal profile of him and label him a priestcollaborator while, in other parts of their book, they describe him mostly as an opportunist deeply loyal to the Communist Party. In some marginal comments and in photograph captions, they also describe him as a charismatic speaker, a person with an antifascist reputation. In many pictures we can see him surrounded by large audiences, appearing as a friendly person in the presence of various intellectuals-including some French priests and journalists, and among politicians at various public events.
} 
gymnasium in his hometown, he was active in German student associations. His German schoolmates at Catholic seminary considered him German and he was slated to become a priest in the German-speaking community. However, he considered himself to be Czech (at least in 1930s and later on), which, together with his political activity in Czechoslovak People's Party, caused him to be politically persecuted during the Nazi occupation. During the war he was arrested by the Gestapo in 1939 and deported to Buchenwald and, later, to Dachau where, at the time of liberation, he was a member of the Czechoslovak National Committee.

In the early 1930s Plojhar became politically active as a member of the Czechoslovak People's Party, which was deeply connected with the Catholic Church. He published a local church journal, Farní věstnik. During the political crisis in February 1948 he called upon his party to be open to collaborating with the Communist Party-because of this, he was briefly expelled from the party. When the Communist Party created a new government, he joined some other left-wing members of the party to establish a new leadership of the People's Party and became its vice-president (1948-1951). After the death of the party's president, Plojhar became the head of the party (1951-1968). Although he was a Catholic priest, he became minister of health in Communist governments. He was not only the longest-serving minister in the history of Czechoslovakia (from 1948 to 1968), he also managed to keep this position in both Stalinist and de-Stalinizing governments-under Klement Gottwald (1948), Antonín Zápotocký and Viliam Široký (1948-54), Viliam Široký again (1954-1963) and Jozef Lenárt (1963-1968). As a non-Communist and as a representative of a political party included in the National Front of legal political parties, he was also a member of several Czechoslovak parliaments from 1945 to 1960 and from 1976 to 1981. Even after the mid-1950s, when the Communist Party prohibited priests from becoming Party members and from serving in high-ranking political positions, Plojhar continued to be able to occupy high-ranking political positions. Plojhar was also vice-president of the Association of Czechoslovak-Soviet Friendship (1952-1970).

As a Catholic priest, Plojhar was active in establishing and heading a new Catholic organization, which was at first known as the "progressive priests" and was later generally called the "Peace Movement." It existed under various forms and names, from 1948 to 1951 as the Movement of Catholic Priests, from 1951 to 1968 as the National Committee of Catholic Priests and 
the Peace Movement of Catholic Priests. The organization was formed on the principles of equality among all members, which meant for example the elimination of the hierarchical relationship between priests and bishops. According to Kadlecová (1990: 18), this organization underwent the same kind of radical changes experienced by all institutions in Czechoslovakia after 1948. In the end it became nothing but "the long arm of state institutions." At the beginning of the Prague Spring, in March 1968, the association was "selfliquidated." In the years of political change (1948-1949) Plojhar experienced "loyalty issues" having to choose between his loyalty to the Catholic Church or to the political regime. For example, after the establishment of the so-called "Catholic Action 1949," he first supported the initiative, but took back his signature after the church excommunicated the supporters of the Catholic Action (Balík and Hanuš 2013: 23).

While Plojhar was able to be politically active and involved in the creation of the new system in 1948, he came to be seen primarily as a symbol of the regime after twenty years of his political career. Many in the 1960 considered him compromised by his collaboration with the unpopular official structures, and his organizations effectively became state institutions and part of an integrated system. During the Prague Spring, he was removed from his post at the ministry of health and also from his position at the head of the Czechoslovak People's Party. After the invasion of Czechoslovakia by the Warsaw Pact armies, he became again president of the party on a honorary basis. He died in 1981 at the Soviet embassy in Prague during a celebration of the "Great Soviet Revolution of October 1917." Cardinal František Tomášek, ${ }^{12}$ from his position as the Primate of Catholic Church in Czechoslovakia, refused to conduct a Catholic ceremony for Plojhar, and his funeral was conducted by another Catholic priest.

Plojhar's case provides an example of the double role of religion, and especially of the Catholic Church, during the political changes in 1948 and

\footnotetext{
${ }^{12}$ František Tomášek was for a short time a member of presiding council of the "peace movement" in 1948, but later he was clandestinely consecrated as a secret bishop and later was arrested by the regime. In 1965, at the recommendation of Plojhar and in common agreement between Czechoslovakia and the Vatican, Tomášek was installed as Prague Archbishop. The regime considered Tomášek as "its person" (Balík and Hanuš, 2013). In 1976 he was appointed to be the position of cardinal, but this information was not made public until 1977. In 1977 he did not support the Charter77, but at the end of 1970s he came to more openly declare his opposition toward the political regime in Czechoslovakia. He came to be promoted as a symbol by Western politicians. In the beginning of the 1980s he declared that the "peace movement" was not Catholic. During the "Velvet Revolution" in November 1989, he came to be a one of the revolution's symbols.
} 
after. His story can be seen as the story of one post-WWII branch of Catholicism, "New Catholicism," and contains all the contradictions and political tensions of this historical period. ${ }^{13}$ As a complement to the top-down structural analysis that is the main approach applied in this article, this bottom-up investigation of progressive (also called "patriotic") movements inside of the church, as well as the stories of some important personalities of this movement, seems useful. However, it can only be reconstructed from the fragments that have appeared in the secondary literature on this period of Czechoslovak history. This kind of history, I argue, can show in a more detailed and less moralistic way the tragedy of great transformations in a society. ${ }^{14}$

\footnotetext{
${ }^{13}$ By contrast, since 1989 a huge amount of scholarly as well as popular biographical literature has been devoted to those priests and church members who were persecuted during the period of Communist Party rule, mostly in the years 1948-1965. This imbalance in sources creates the impression that there were only a few "fallen" and "corrupted" priests or believers who collaborated with the communists, and their collaboration is usually described as a problem of their character and their personal failure.

${ }^{14}$ This study was prepared with the support of the Slovak Research and Development Agency under the contract No. APVV-0627-12.
} 


\section{Annex}

The following tables illustrate the development of the conflict between the Communist Party and the Catholic Church. In general, the conflict subsided in the mid 1950s and the situation remained stable thereafter, with the exception of the short period of the Prague Spring in 1968 when some attempts were made by reformists in the Communist Party as well as by some religious initiatives to weaken the strict control and regulation of religious life. The consequences of this conflict were manifested in specific church legislation that was applied to all religious groups in Czechoslovakia.

Table 1: The beginning of symmetrical schismogenesis (1948)

\begin{tabular}{|c|c|}
\hline Communist Party (CP) & Catholic Church (CC) \\
\hline $\begin{array}{l}\text { 25/2: Communist Party takes power after } \\
\text { dissolution of the previous government }\end{array}$ & $\begin{array}{l}\text { 26/2: Archbishop declares that change of power is } \\
\text { an illegal act }\end{array}$ \\
\hline \multicolumn{2}{|l|}{$\begin{array}{l}\text { March 1948: collaboration with priests in } \\
\text { establishing "Action Fives" }\end{array}$} \\
\hline \multicolumn{2}{|l|}{$\begin{array}{l}\text { 18/3: National Front issues declaration of } \\
\text { religious freedom as pillar of people's democracy }\end{array}$} \\
\hline & $\begin{array}{l}\text { 3/5: Prohibits priests from becoming members or } \\
\text { nominees of political parties or participating in } \\
\text { parliamentary elections - punishments issued } \\
\text { according to canonical law (some priests give up } \\
\text { membership in CP) }\end{array}$ \\
\hline $\begin{array}{l}\text { June: Some priests elected to parliament and } \\
\text { government }\end{array}$ & $\begin{array}{l}\text { Church rescinds suspension of priests involved in } \\
\text { politics }\end{array}$ \\
\hline $\begin{array}{l}\text { 14/6: Te Deum performed by Prague archbishop } \\
\text { for Communist president Gottwald }\end{array}$ & $\begin{array}{l}\text { In the same day Vatican protests against Te Deum } \\
\text { 15/6: Archbishop explains the meaning of Te Deum } \\
\text { as not support for communist ideology and } \\
\text { confirms that Communism is in contradiction with } \\
\text { church teachings }\end{array}$ \\
\hline
\end{tabular}

19/7: New government declares desire to maintain positive relationship with churches, which contribute to the cohesion of society

30 / 8: Proposal of the Central Committee of the Communist Party for solving the church question: churches must not become tools used against the regime 
Table 2: Continuation of symmetrical schismogenesis (1949)

\section{Communist Party (CP)}

by the Vatican labelled as an anti-state action

April 1949: Declaration of intent to form Catholic
Action
10 / 6: Catholic Action established as a "revitalizing
movement in the church"; weekly Catholic
Newspaper established as mouthpiece for Catholic
Action

June: Military intervenes to quell conflict between some priests and various groups of laics ${ }^{16}$

July: After papal decree, some members of clergy and laity renounce membership in $\mathrm{CP}$

July-August: Prison sentences given to some priests who refuse to perform ceremonies for people connected with Communists

Autumn 1949: "church legislation" passed salaries of priests paid from public budget; churches regulated; equality of all churches under state control guaranteed

\section{9/10.: Amnesty for 127 priests imprisoned for} actions against state

\section{Catholic Church (CC)}

January 1969: Creation of secret and parallel structures and hierarchy in the church

Vatican declares all suspensions punishment for breaking canonical discipline

28/5: Canonical punishments issued for all supporters of the Catholic Action

15/6: Organizers of the Catholic Action excommunicated by Czechoslovak bishops

20/6: Organizers of the Catholic Action excommunicated by Pope

1/7: Pope issues decree on Communism; calls for excommunication of all promoters of Communism and Marxism

Church prohibits reading weekly Catholic Newspaper, which is declared a non-Catholic periodical

31/7: in Eastern Slovakia, church's excommunication decree read 4-5 times daily along with list of people excommunicated

Higher clergy protest against legislation while lower clergy support it (several hundred people visit parliament and thank government for legislation; $70 \%$ priests support it)

November: Only four priests refuse to accept salaries from the state

14/10: Clandestine (secret) consecration of bishops ("secret bishops") $)^{17}$

\footnotetext{
${ }^{15}$ The goal of this movement was to integrate progressive priests and lay church members and to create a new church under the leadership of the progressive priests. Priest were not, however, members of the organization's presiding council. The majority of Catholic Action members were members of both the Communist Party and the Catholic Church. After the movement failed to gain broader support and influence, it was disbanded in the 1950.

${ }^{16}$ There were a number of conflicts at that time. Some groups of laity kept guard to protect their priests against persecution after they read the excommunication decree issued by the bishops and the Pope. Another lay church members attacked priests who replaced arrested priests. Some of the laity attacked priests who did not support the government's "development program."

${ }^{17}$ The clandestine consecration of priests and bishops continued until the end of the 1960s. Many of them were consecrated without the agreement of the Vatican, which caused a number of problems after 1989 relating to their authorization by the Vatican. In addition, some married men and some women were consecrated as priests.
} 
Table 3: Complementary schismogenesis (1950-1952)

\begin{tabular}{l|l|}
\hline Communist Party & Catholic Church \\
\hline Beginning February: Some bishops put on trial & January 1950: Priests promise loyalty to Republic \\
\hline $\begin{array}{l}\text { 28/4: Action P (pravoslavizácia - the } \\
\text { Orthodoxisation of Greek Catholics) - that is, the } \\
\text { legal integration of the Greek Catholic Church } \\
\text { into the Orthodox Church (against the will of } \\
\text { most priests and lay members) }\end{array}$ & $\begin{array}{l}\text { 2.3. 1950: Pope criticises Communism; grants } \\
\text { amnesty to those excommunicated }\end{array}$ \\
\hline $\begin{array}{l}\text { 13-14/4: Action K (Kláštor - monastery) - male } \\
\text { religious orders abolished and orders' property } \\
\text { nationalised }\end{array}$ & \\
$\begin{array}{l}\text { 29-30/8: Action R (Rehole - orders) -female } \\
\text { religious orders abolished }\end{array}$ & \\
\hline
\end{tabular}

17/3/1951: Vatican excommunicates those who take action against bishops in collaboration with civil institutions

9/4/1951: Vatican excommunicates those who consecrate bishops without Vatican permission

August 1951: Trial against "Vatican spies," i.e.

Catholic priests

\section{Bibliography}

Balík, S. and J. Hanuš (2013). Katolická církev v Československu 1945-1989. Brno: CDK.

Bancíková, D. (undated). Divné sú cesty Božie. Samizdat. Accessed June 1, 2015. http: / / www.d-pro.sk/detm/Bancikova-Darina-Divne-su-cestyBozie.pdf 
Bateson, G. (1972). Steps to an Ecology of Mind. Collected Essays in Anthropology, Psychiatry, Evolution, and Epistemology. Chicago: University of Chicago Press.

Bourdieu, P. (1990). The Logic of Practice. Stanford CA: Stanford University Press.

Čikeš, R. (2010). Vztahy štátu a cirkví na Slovensku. Súčasné usporiadanie a trendy vo vývoji vzt'ahu štátu a cirkví. Bratislava: Ústav pre vztáahy štátu a cirkvi.

Kadlecová, E. (1990). Záznam rozhovoru s pani doktorkou Erikou Kadlecovou, CSc. s dr. Vlašánem a dr. Povolným, 27.6.1990 (interview with E. Kadlecová, 27 June 1990).

Kepel, G. (1991). La revanche de Dieu. Chrétiens, juifs et musulmans à la reconquête du monde. Paris: Le Seuil.

Kmet', N. (2000). Postavenie cirkví na Slovensku 1948-1951. Bratislava: VEDA.

- (2014). Snahy ateizovat' veriacich ako prejav cirkevnej politiky na Slovensku počas normalizácie. In. Pažout, J. (ed.), Informační boj o Československo/v Československu (1945-1989), Prag: Ústav pro studium totalitních režimů, Technická univerzita v Liberci: 174-189.

Krapfl, J. (2014). Revolution with a Human Face. Politics, Culture, and Community in Czechoslovakia 1989-1992. Ithaca and London: Cornell University Press.

Kvasničková, A. (2005). Náboženstvo ako kolektívna pamät: prípad Slovenska a Čiech. Bratislava: Univerzita Komenského v Bratislave.

Mišovič, J. (2001). Víra v dějinách zemí Koruny České. Prag: Sociologické nakladatelství.

Pešek, J. and M. Barnovský (1997). Štátna moc a cirkvi na Slovensku 1948-1953. Bratislava: VEDA.

—. (1999). Pod kuratelou moci. Cirkvi na Slovensku v rokoch 1953-1970. Bratislava: VEDA.

Pullman, M. (2011). Konec experimentu. Přestavba a pád komunismu v Československu. Prag: Scriptorium.

Stehlík, M. (2008). "Je vhodná doba se s nimi vypořádat..." Úloha cirkevních oddelení Krajského národniho výboru Jihlava a Okresniho národniho výboru Moravské Budějovice v případu Babice v roce 1951. Pamět a dějiny, 1: 53-59.

Tížik, M. (2011). Náboženstvo vo verejnom živote na Slovensku. Zápasy o ideový charakter štátu a spoločnosti. Bratislava: Sociologický ústav SAV.

Václavík, D. (2010). Náboženství a moderní česká společnost. Prag: Grada Publishing. 